\title{
Validity and reliability fatigue severity scale in patients with Systemic Lupus Erythematosus (SLE) in Indonesia
}

\author{
A Rifa'i', H Kalim¹, Kusworini², CS Wahono
}

\begin{abstract}
${ }^{1}$ Division of Rheumatology and Immunology, Department of Internal Medicine, Brawijaya University / dr.Saiful Anwar Hospital Malang. ${ }^{2}$ Department of Clinical Pathology, Brawijaya University / dr. Saiful Anwar Hospital Malang
\end{abstract}

\begin{abstract}
Background: Fatigue is one symptom of Systemic Lupus Erythematosus (SLE), which has an important effect on the quality of life. Fatigue Severity Scale (FSS) is one parameter fatigue symptom in SLE. The purpose of this study was to determine the validity and reliability between FSS with duration of ilness and disease activity of SLE patients in Indonesia.

Methods: FSS performed on 40 patients with SLE. FSS original English version has been converted-translated into Indonesian version by a team of RheumatologyImmunology Medical Faculty of Brawijaya University. Reliability determined by Cronbach's Alpha values $(>0.6)$. Validity was determined by the value of Corrected Item-Total Correlation which each item was a valid question if below value of Cronbach's Alpha.

Results: The reliability value was determined by Cronbach's Alpha values ( $>0.6)$ in which the SLE patients in this study had a Cronbach's Alpha value of 0.946. Value of Corrected Item-Total Correlation overall under Cronbach's Alpha value (range $=0.684-0.859$ ) which indicates that each item was a valid question. There were correlation between the FSS Indonesian version with disease duration $(p=0.000)$ as well as the value of $r=0.581$, with SLEDAI $(p=0.000)$ with a value of $r=0.833$.

Conclusion: FSS in Indonesian version has a good reliability and validity and can be used by clinicians and other researchers to assess the condition of fatigue in SLE patients in Indonesia.

Keywords: validity, reliability, fatigue, fatigue severity
\end{abstract} scale, systemic lupus erythematosus

\section{Background}

Systemic Lupus Erythematosus (SLE) is a chronic autoimmune disease which has varied systemic clinical manifestations as well as the emergence of 'flare' or remission is difficult to predict.'

Fatigue is one of the symptoms associated with inflammatory disease. It can caused by many factors, among others, the degree of disease activity, medical therapy, or comorbid conditions such as depression and fibromyalgia. ${ }^{2}$ Fatigue has a high prevalence in patients with SLE (67-90\%) and may be the most dominant symptom, limiting daily activities of patients and the effect on patient compliance in the treatment process. ${ }^{2,3}$ Fatigue, though often experienced, quite difficult to measure because it is subjective and heterogenous.
However, several methods have been made to measure/assess. An International $\mathrm{Ad} \mathrm{Hoc}$ Committee has recommended the instrument can validate the condition of fatigue in patients with SLE, the Fatigue Severity Scale (FSS) in the original version in English. ${ }^{4,5}$ The FSS consists of nine items of questions about symptoms of fatigue, each item has a score ranging from one to seven. FSS has been translated into several languages, ${ }^{6-8}$ however to date, translation of the FSS into Indonesian has not been done. The purpose of this study was to determine the validity and reliability of Fatigue Severity Scale (FSS) in patients with SLE in Indonesia.

\section{Methods}

The study was conducted in the outpatient unit Rheumatology division of the Internal Medicine Department, RSSA Malang. FSS original English version has been converted-translated into Indonesian version by a team of RheumatologyImmunology the Medical Faculty of the Brawijaya University.

\section{Population and Sample Research}

The population was affordable on the SLE patients who seek treatment in the Hospital Clinic of Internal Medicine Dr. Saiful Anwar. SLE diagnosis based on the 1997 ACR criteria. Sampling technique was consecutive sampling that all subjects who came and met the inclusion criteria based on a predetermined time. Inclusion and control subjects were women with SLE, aged 18-43 years, disease duration $\leq 1$ year since SLE diagnosed, the disease was active with SLEDAI scores $\geq 5$. Subjects who signed informed consent had initial examination to diagnose, physical examination, determined SLEDAI score and FSS score. This study was approved by the Ethics Committee of the Medical Faculty of the Brawijaya University.

\section{Statistical Analysis}

Internal consistency reliability was tested by using Cronbach's alpha, where the value $>0.7$ means satisfactory, while the value of $>0.9$ can be used clinically. ${ }^{14,15}$ Validity was determined by the value of Corrected Item-Total Correlation where each item was a valid question if below value Cronbach's Alpha. ${ }^{9}$ Validity was tested by Spearman's rank correlation coefficient (rS) to describe the 
correlation between the FSS with disease duration and degree of disease activity (SLEDAI). rS values $\leq 0.25$ is a little or no correlation, 0.26 to 0.49 showed weak correlation, 0.50 0.69 showed moderate correlation, $0.70-0.89$ showed a strong correlation, and $0.90-1.0$ showed a very strong correlation. ${ }^{9}$ Statistical analysis was performed with SPSS (Statistical Package for the Social Sciences) version 17.0.

\section{Results}

The data of total 40 patients who participated in this study showed in Table 1.

Table 1 Characteristics of SLE Patients

\begin{tabular}{lcc}
\hline Characteristics & Range & Mean (SD) \\
\hline Age (years) & $16-40$ & $28.25(6.97)$ \\
\hline $\begin{array}{l}\text { Disease Duration } \\
\text { (month ) }\end{array}$ & $1-8$ & $3.55(1.90)$ \\
\hline SLEDAl & $7-23$ & $12.65(4.85)$ \\
\hline FSS & $3-7$ & $5.41(1.02)$ \\
\hline
\end{tabular}

The average age of SLE patients was 28.25 (SD 6.97) years (range 16 - 40 years old). The average of duration disease was 3.50 (SD 1.90) months. The average SLEDAI score of patient was 12.65 (SD 4.84), while the average of FSS score was 5.41 (SD 1.02).

Table 2 Translations FSS into Indonesian

\begin{tabular}{ll}
\hline English Version & Indonesian Version \\
\hline $\begin{array}{l}\text { My motivation is lower, } \\
\text { when I am fatigued }\end{array}$ & $\begin{array}{l}\text { Motivasi saya rendah sekali saat saya } \\
\text { mengalami kelelahan }\end{array}$ \\
\hline $\begin{array}{l}\text { Exercise brings on my } \\
\text { fatigue }\end{array}$ & $\begin{array}{l}\text { Latihan fisik mengakibatkan saya } \\
\text { mengalami kelelahan }\end{array}$ \\
\hline I am easily fatigued & Saya mudah sekali mengalami kelelahan \\
\hline $\begin{array}{l}\text { Fatigue interferes with my } \\
\text { physical functioning }\end{array}$ & Kelelahan mengganggu aktifitas fisik saya \\
\hline $\begin{array}{l}\text { Fatigue causes frequent } \\
\text { problems for me }\end{array}$ & Kelelahan sering menjadi masalah saya \\
\hline $\begin{array}{l}\text { My fatigue prevents } \\
\text { sustained physical } \\
\text { functioning }\end{array}$ & $\begin{array}{l}\text { Kelelahan menyebabkan saya tidak bisa } \\
\text { bertahan lama dalam beraktifitas }\end{array}$ \\
\hline $\begin{array}{l}\text { Fatigue interferes with } \\
\text { carrying out certain duties } \\
\text { and responsibilities }\end{array}$ & $\begin{array}{l}\text { Kelelahan mempengaruhi tugas dan } \\
\text { tanggung jawab saya }\end{array}$ \\
\hline $\begin{array}{l}\text { Fatigue is among my 3 } \\
\text { most disabling symptoms }\end{array}$ & $\begin{array}{l}\text { Kelelahan merupakan salah satu dari 3 } \\
\text { gejala utama yang membatasi aktifitas } \\
\text { saya }\end{array}$ \\
\hline $\begin{array}{l}\text { Fatigue interferes with my } \\
\text { work, family, or social life }\end{array}$ & $\begin{array}{l}\text { Kelelahan mempengaruhi pekerjaan, } \\
\text { keluarga atau kehidupan sosial saya }\end{array}$ \\
\hline
\end{tabular}

\section{Reliability and validity of FSS}

Reliability is determined by the value of Cronbach's Alpha values $(>0.6)$ in which the SLE patients in this study had a Cronbach's Alpha $=0.946$. As for the validity of the FSS can be seen in Table 3.
Table 3 Validity Fatigue Severity Scale (FSS)

\begin{tabular}{ll}
\hline \multicolumn{1}{c}{ Item question } & \multicolumn{1}{c}{$\begin{array}{c}\text { Corrected Item- } \\
\text { Total Correlation }\end{array}$} \\
\hline $\begin{array}{l}\text { Motivasi saya rendah sekali saat saya } \\
\text { mengalami kelelahan }\end{array}$ & 0.770 \\
\hline $\begin{array}{l}\text { Latihan fisik mengakibatkan saya mengalami } \\
\text { kelelahan }\end{array}$ & 0.761 \\
\hline Saya mudah sekali mengalami kelelahan & 0.831 \\
\hline Kelelahan mengganggu aktifitas fisik saya & 0.715 \\
\hline Kelelahan sering menjadi masalah saya & 0.859 \\
\hline $\begin{array}{l}\text { Kelelahan menyebabkan saya tidak bisa } \\
\text { bertahan lama dalam beraktifitas }\end{array}$ & 0.842 \\
\hline $\begin{array}{l}\text { Kelelahan mempengaruhi tugas dan tanggung } \\
\text { jawab saya }\end{array}$ & 0.794 \\
\hline $\begin{array}{l}\text { Kelelahan merupakan salah satu dari 3 gejala } \\
\text { utama yang membatasi aktifitas saya }\end{array}$ & 0.684 \\
\hline $\begin{array}{l}\text { Kelelahan mempengaruhi pekerjaan, keluarga } \\
\text { atau kehidupan sosial saya }\end{array}$ & 0.858 \\
\hline
\end{tabular}

The Corrected Item-Total Correlation value overall were under Cronbach's Alpha value (range $=0.684-0.859$ ) which indicated that each item was a valid question. This study showed the correlation between the FSS with duration of illness and disease activity (Table 4). There were relationship between the FSS and duration of illness because the value of $p$ $<0.05(\mathrm{p}=0.000)$ with $\mathrm{rS}=0.581$

Table 4 The correlation of FSS with duration of illnes disease activity of LES patients

\begin{tabular}{cccc}
\hline No & \multicolumn{1}{c}{ Variabel } & $\boldsymbol{P}$ & $\boldsymbol{r}$ \\
\hline 1. & FSS with duration of ilness & 0.000 & 0.581 \\
\hline 2. & FSS with disease activity & 0.000 & 0.833 \\
\hline $\mathrm{P}<0.005$ significant relationship & &
\end{tabular}

There were also significant relationship between the FSS and disease activity (SLEDAI) because $p<0.05(p=0.000)$ with $\mathrm{rS}=0.833$

\section{Discussion}

This study reported that FSS-English version translated into Indonesian version and subsequently tested for validity and realibility in SLE patients whose disease onset $<1$ year. Proven reliability with Cronbach's Alpha value. While the validity value also indicated that all items of FSS questions Indonesian version were valid.

Clinical features of SLE were varied, the European League Against Rheumatism (EULAR) recommended the use of quality of life assessment in clinical practice because the data was relevant or even overlooked. ${ }^{10}$ In this study FSS Indonesian version were valid to be used for clinical practice. Until now, fatigue evaluation performed by anamnesis/history of the patient, while the use of questionnaires have not been routinely performed in clinical practice. ${ }^{10}$ Assessment of patients, such as FSS can contribute to the evaluation of the SLE patient's health condition subsequent, both during daily clinical examination or for further treatment. 
The validity and reliability in this study is consistent with the results of several previous studies. Reliability values respectively with Cronbach's alpha 0.89 on research conducted by Neuberger, 0.96 in the study by Lorentzen and 0.953 on Bakalidou study. ${ }^{11,9,12}$

Besides, in this study it was found that a significant relationship between FSS and duration of illness and also with disease activity. Correlation with duration of illness has moderate power that means the longer duration of illness, the possibility of fatigue conditions in SLE patient were more severe. In disease activity, some research suggests that controversial results in terms on one side has a correlation but on the other hand does not exist. ${ }^{13-16}$ In this study, there were significant relationship with a positive correlation, but it occurs in patients with a limited population, patients with disease duration of less than 1 year. Although weak positive correlation was also reported in the study conducted by Lorentzen. ${ }^{9}$

\section{Conclusion}

This study indicated that Indonesian version of the FSS was valid and reliable method of measuring fatigue in patients with Systemic Lupus Erythematosus (SLE). It shows the role of the patient's clinical surveillance because it will give opportunity for SLE patient to measure and report the prevalence of symptoms that are important for quality of life.

\section{References}

1. Gurevitz SL, Synder JA, Wessel EK, Frey J, Williamson BA. Systemic lupus erythematosus : a review of the disease and treatment options. Consult Pharm 2013;28(2):110-21.

2. Cleanthous S, Tyagi M, Isenberg DA, Newman SP. What do we know about self reported fatigue in systemic lupus eryhtematosus?. Lupus 2012;21(5):465-76.

3. Kiani AN, Petri M. Quality-of-life measurements versus disease activity in systemic lupus erythematosus. Curr Rheumatol Rep 2010;12:250-8.
4. Measurement of fatigue in systemic lupus erythematosus: a systematic review. Arthritis Rheum 2007:57:1348-57.

5. Krupp LB, LaRocca NG, Muir-Nash J, Steinberg AD. The fatigue severity scale. Application to patients with multiple sclerosis and systemic lupus erythematosus. Arch Neurol 1989;46(10):1121-3.

6. Gencay-Can A, Can SS. Validation of the Turkish version of the fatigue severity scale in patients with fibromyalgia. Rheumatol Int 2012;32:2731.

7. Laranjeira CA. Translation and adaptation of the fatigue severity scale for use in Portugal. Appl Nurs Res 2012;25:212-7.

8. Mattsson M, Möller B, Lundberg le, Gard G, Boström C. Reliability and validity of the Fatigue Severity Scale in Swedish for patients with systemic lupus erythematosus. Scand J Rheumatol 2008;37(4):269-77.

9. Lorentzen K, Danielsen MA, Susan Due Kay, Voss A. Validation of the Fatigue Severity Scale in Danish patients with systemic lupus erythematosus. Dan Med J 2014;61(4):A4808.

10. Mosca M, Tani C, Aringer M, Bombardieri S, Boumpas D, Brey R, et al. European League Against Rheumatism recommendation for monitoring patients with systemic lupus erythematosus in clinical practice and in observational studies. Ann Rheum Dis 2010;69(7):1269-74.

11. Neuberger GB. Measures of fatigue: The fatigue questionnaire, fatigue severity scale, and short form-36 vitality (energy/fatigue) subscale of the short form health survey. Arthritis Rheum 2003: 49(5S): 175-83.

12. Bakalidou D, Skordilis EK, Giannopoulos S, Stamboulis E, Voumvourakis K. Validity and reliability of the FSS in Greek MS patients. Springerplus 2013;2(1):304

13. Burgos PI, Alacron GS, McGwin G Jr, Crews KQ, Reveille JD, Vilá LM. Disease activity and damage are not associated with increased levels of fatigue in systemic lupus erythematosus patients from a multiethnic cohort: LXVII. Arthritis Rheum 2009; 61 (9): 1179-86.

14. Da Costa D, Dritsa M, Bernatsky S, Pineau C, Ménard HA, Dasgupta K, et al. Dimensions of fatigue in systemic lupus erythematosus: relationship to disease status and behavioral and psychosocial factors. J Rheumatol 2006; 33(7): 1282-7.

15. McKinley PS, Ouellette SC, Winkel GH. The contributions of disease activity, sleep patterns, and depression to fatigue in systemic lupus erythematosus. Arthritis Rheum 1995; 38(6): 826-34.

16. Wang $B$, Gladman DD, Urowitz MB. Fatigue in lupus is not correlated with disease activity. J Rheumatol 1998; 25(5):892-5. 